\title{
INSULIN RESISTANCE IN PATIENTS WITH NEWLY DIAGNOSED PULMONARY TUBERCULOSIS WITH DIFFERENT TREATMENT OUTCOME
}

\author{
Zaporizhzhia State Medical University
}

The aim of the study - to evaluate fasting glucose, insulin levels and homeostasis model assessment (HOMA$I R)$ index in patients with newly diagnosed pulmonary tuberculosis treatment failure (TFT) compared to data of patients who have successfully completed course of treatment (NDT).

Materials and methods. 49 newly diagnosed pulmonary tuberculosis patients were examined. Patients were divided into 2 groups. Group 1 included 28 patients with TFT. Group 2 (comparison group) included 21 NDT patients. Blood sampling in the patients was done before treatment, after 3 months of the treatment start and after 2-3 months of treatment of patients in the group 1. Fasting plasma glucose level was determined by the hexokinase method by using Beckman Coulter AU640 biochemical analyzer, Japan. Fasting serum insulin level was determined by electrochemiluminescence method on Cobas e411 analyzer, Switzerland. Insulin resistance index was calculated by HOMA-IR by Matthews et al., 1985.

Results. Fasting glucose levels were normal and almost similar in both groups before and after treatment, $p>0.05$. Fasting insulin levels were also normal, but they were higher in patients of the group 1 than in the group 2, $p<0.05$. It means there was a relative slight hyperinsulinemia in TFT patients. HOMA-IR index was also significantly greater among patients in the group 1, $p<0.05$. Fasting glucose levels increase was in $10.7 \%$ of patients in the group 1 and in $4.8 \%$ patient in the group 2. Decrease of glucose levels was in $4.8 \%$ of patients from the group 2. Fasting insulin levels increase was determined in 1 case among the group 1 patients and there were not cases with increased insulin levels among the patients of the group 2; fasting insulin levels reduction was identified in $14.3 \%$ of patients from the group 1 only, $p>0.05$. There was HOMA-IR index increase among patients of the group 1 mostly: 9 cases (33.3\%) versus 1 case (4.8\%) in the group 2, $p<0.05$. Thus, a relative slight hyperinsulinemia in normal glucose levels and HOMA-IR index increase could be a signs of preclinical disorders of carbohydrate metabolism in patients with TFT.
Conclusion. It may indicate negative impact of virulent mycobacteria and more severe clinical and radiological changes on carbohydrate metabolism or/and negative impact of such disorders to prognosis of tuberculosis.

Key words: insulin resistance; tuberculosis; treatment outcome.

Insulin resistance (IR) is a preclinical disturbance of carbohydrate metabolism and takes place in infectious diseases, in particular, in tuberculosis. Such a metabolic disorder can lead not only to the appearance of heart diseases and diabetes, but it is connected with changes in the immune system, which may contribute to tuberculosis [1-6]. Metabolic disorders, including IR may occur not only in obese patients [7], thus, IR and tuberculosis could be closely related. There is activation of the hypothalamic-pituitary-adrenocortical system, which has insulin counterregulatory effect in tuberculosis. IR can occur also because of oxidative stress increase in conditions of functional activity of antioxidant protection system reduction, in particular, glutathione system. There is an assumption that IR caused by tumor necrotic factor $\alpha$ increasing in tuberculosis patients. It could stimulate free fatty acids production that could cause hyperglycemia and IR [1, 2, 5]. Mycobacterium tuberculosis (MBT) could persist in macrophages, adipocytes for a long time and could cause functional disorders in these cells, including insulin resistance [12]. On the other hand, IR causes weakening of macrophages phagocytic activity and leads to increased production of hydrogen peroxide by macrophages that enhance oxidative stress in cases of antioxidant protection system reduction [8].

In previous studies, preclinical disorders of carbohydrate metabolism in patients with tuberculosis have already been studied. MBT infection induces IR and chronic hyperglycemia in guinea pigs [5]. There might be a slight compensatory hyperinsulinemia, and persistent hyperglycemia with further insulin deficiency and glucose intolerance in tuberculosis patients. Hyperglycemia could also have a toxic effect on the insular apparatus of pancreas. The ap- 
pointment of anti-tuberculosis therapy did not normalize preclinical disorders of carbohydrate metabolism, indicating their primacy in relation to tuberculosis $[1,2]$.

Mainly IR was estimated by glucose, insulin blood levels and oral glucose tolerance test in previously researches. HOMA-IR index calculation is valid method for IR detection $[7,9,10]$. There are different data on HOMA-IR levels in tuberculosis patients. Yurt S. et al. detected higher HOMA-IR levels in tuberculosis patients in comparison with control and other diseases data [3]. Thanoon I.A.J. and Aded-Alrahman A.A.A. noted that there were not significant changes in HOMA-IR level in tuberculosis patients in comparison with control (healthy volunteers) before treatment and in tuberculosis patients before and after treatment [11].

Thus, IR, measured by HOMA-IR calculation could be a prognostic factor for tuberculosis course because of its connection with anti-tuberculosis immunity. It was studied in tuberculosis patients in some researches and compared with other diseases, before and after treatment, the data were different. The effect of insulin resistance on the outcome of treatment of pulmonary tuberculosis patients is insufficiently researched. That's why this problem needs further investigation.

The aim of the study - to evaluate fasting glucose, insulin levels and HOMA-IR index in patients with newly diagnosed pulmonary tuberculosis treatment failure compared to data of patients who have successfully completed course of treatment.

\section{Materials and methods}

49 newly diagnosed pulmonary tuberculosis patients were examined. Criteria for inclusion in the study: newly diagnosed pulmonary tuberculosis; age from 18 to 70 years. Exclusion criteria: concomitant illnesses and conditions with severe functional disorders, HIVIAIDS, diabetes mellitus, cancer diseases, lack of adherence to treatment, alcoholism, drug addiction. Patients were divided into 2 groups. Group 1 included 28 patients with treatment failure (TFT). There were 18 male (64.3\%) and 10 female (35.7\%) patients in the group 1. The average age was (48.4 \pm 2.1 ) years. Group 2 (comparison group) included 21 patients, who have successfully completed a course of treatment (NDT). There were 14 male (66.7\%) and 7 female (33.3\%) patients in this group. The average age was $(43.7 \pm 3.1)$ years. So, groups were represented by gender and age, $\mathrm{p}>0.05$.

Disseminative tuberculosis was diagnosed in 19 $(67.9 \%)$ in patients of the group 1 and $10(47.6 \%)$ patients of the group 2. Infiltrative - in 7 (25.0\%) and 9 (42.9\%) patients, respectively, fibrous-cavernous tuberculosis was diagnosed in $2(7.1 \%)$ in patients of the group 1, focal tuberculosis - in 2 patients $(9.5 \%)$ from the group $2, p>0.05$.
There were 26 patients (92.9\%) with destructions among patients of the group 1 and $12(57.1 \%)$ - among the group $2, p<0.01$. Bacterial excretion was detected in all (100\%) patients of the group 1 and in $24(85.7 \%)$ persons in the group 2, $p>0.05$. Resistance to anti-tuberculosis drugs was defined in $5(17.9 \%)$ cases in the group 1 and in 5 cases $(23.8 \%)$ in the group $2, p>0.05$. It was resistance to isoniazid, streptomycin and isoniazid+streptomycin. So, according to radiological data patients in the group 1 were more severe (75\% of patients with disseminative and fibrous-cavernous tuberculosis versus $47.6 \%$; more, than $92 \%$ with destruction versus $57.1 \%$ ) and because of this treatment failure was diagnosed after 3 months of treatment.

Treatment failure was determined when after 3 months from start of treatment bacterial excretion persisted or if the bacterial excretion resumed before the completion of the course of treatment or if there was negative clinical and radiological dynamics.

Blood sampling in the patients was done before treatment (0 months), after 3 months of the treatment start (in the group 1 - when treatment failure was diagnosed in NDT patients and they were included in TFT group; in the group 2 - when NDT patients finished intensive phase of treatment) and after 2-3 months of treatment of patients of the group 1 (5-6 months). NDT patients were included in the group 2 when they have successfully completed a course of treatment. We compared results of patients in groups before and after treatment (group $1-3$ months and 5-6 months; group 2 - 0 months and 3 months); between groups 1 and 2 - after 3 months of treatment (group 1 3 months and group $2-3$ months).

Fasting plasma glucose level was determined by the hexokinase method by using Beckman Coulter AU640 biochemical analyzer, Japan. Fasting serum insulin level was determined by electrochemiluminescence method on Cobas e411 analyzer, Switzerland. IR index was calculated by homeostasis model assessment of insulin resistance (HOMA-IR) by Matthews et al., 1985.

Statistical analysis was performed by using STATISTICA $®$ for Windows 6.0 (Stat Soft Inc., No. AXXR712D833214FAN5). Statistical significance of differences between groups in qualitative indicators (presence of IR, hyperinsulinemia, hyperglycemia) was determined by the one-tailed Fisher's exact criterion. Statistical significance of differences between groups in quantitative indicators (glucose, insulin levels, IR index) was determined by Mann-Whitney method. For the levels of statistical significance $p$ values levels of less than 0.05 were taken.

\section{Results and discussion}

Fasting glucose levels were normal (according to methodology 4.1-5.9 mmol/l) and almost similar in both groups before and after treatment, $\mathrm{p}>0.05$ (Tab. 1). 
Fasting glucose, fasting insulin levels and HOMA-IR index in newly diagnosed pulmonary tuberculosis patients

\begin{tabular}{|l|c|c|c|c|}
\hline \multirow{2}{*}{ Indicators } & \multicolumn{2}{|c|}{$\begin{array}{c}\text { 1 group (TFT), } \mathrm{n=28,} \\
\mathrm{M} \pm \mathrm{m}\end{array}$} & \multicolumn{2}{c|}{$\begin{array}{c}\text { group (NDT), } \mathrm{n}=21, \\
\mathrm{M} \pm \mathrm{m}\end{array}$} \\
\cline { 2 - 5 } & $\begin{array}{c}\text { at the end of } \\
\text { before treatment } \\
\text { (3 months) }\end{array}$ & $\begin{array}{c}\text { intensive phase } \\
(5-6 \text { months) }\end{array}$ & $\begin{array}{c}\text { at the end of } \\
\text { before treatment } \\
\text { (0 months) }\end{array}$ & $\begin{array}{c}\text { intensive phase } \\
(3 \mathrm{months})\end{array}$ \\
\hline Fasting glucose level, $\mathrm{mmol} / \mathrm{l}$ & $5.3 \pm 0.1$ & $5.3 \pm 0.2$ & $5,2 \pm 0,2$ & $5.2 \pm 0.1$ \\
\hline Fasting insulin level, $\mathrm{mIU} / \mathrm{ml}$ & $11.5 \pm 1.9^{*}$ & $10.4 \pm 1.7$ & $6,9 \pm 1,1$ & $6.9 \pm 0.8^{*}$ \\
\hline HOMA-IR, units & $2.8 \pm 0.6^{*}$ & $2.5 \pm 0.4$ & $1,6 \pm 0,3$ & $1.6 \pm 0.2^{*}$ \\
\hline
\end{tabular}

Note: * - significant difference between 1 (before treatment) and 2 (at the end of intensive phase) groups $(p<0.05)$.

Fasting insulin levels were also normal (according to methodology $2.6-24.9 \mathrm{mIU} / \mathrm{ml}$ ), but they were higher in patients of the group 1 than in the group $2, p<0.05$. It means there was a relative slight hyperinsulinemia in TFT patients. HOMA-IR index was also significantly greater among patients of the group $1 \mathrm{p}<0.05$.

Fasting glucose levels increase was in 3 patients in the group $1(10.7 \%)$ and in 1 patient $(4.8 \%)$ in the group 2 . Decrease of glucose levels was in 1 patient from the group 2 (4.8\%). Fasting insulin levels increase was determined in 1 case (3.6\%) among patients of the group 1 and there were no cases with increased insulin levels among patients of the group 2; fasting insulin levels reduction was identified in 3 patients (14.3\%) from the group 1 only, p>0.05 (Fig. 1).

There was HOMA-IR index increase (more, than 2.7 units) among the group 1 of patients mostly: 9 cases $(33.3 \%)$ versus 1 case $(4.8 \%)$ in the group $2, p<0.05$.

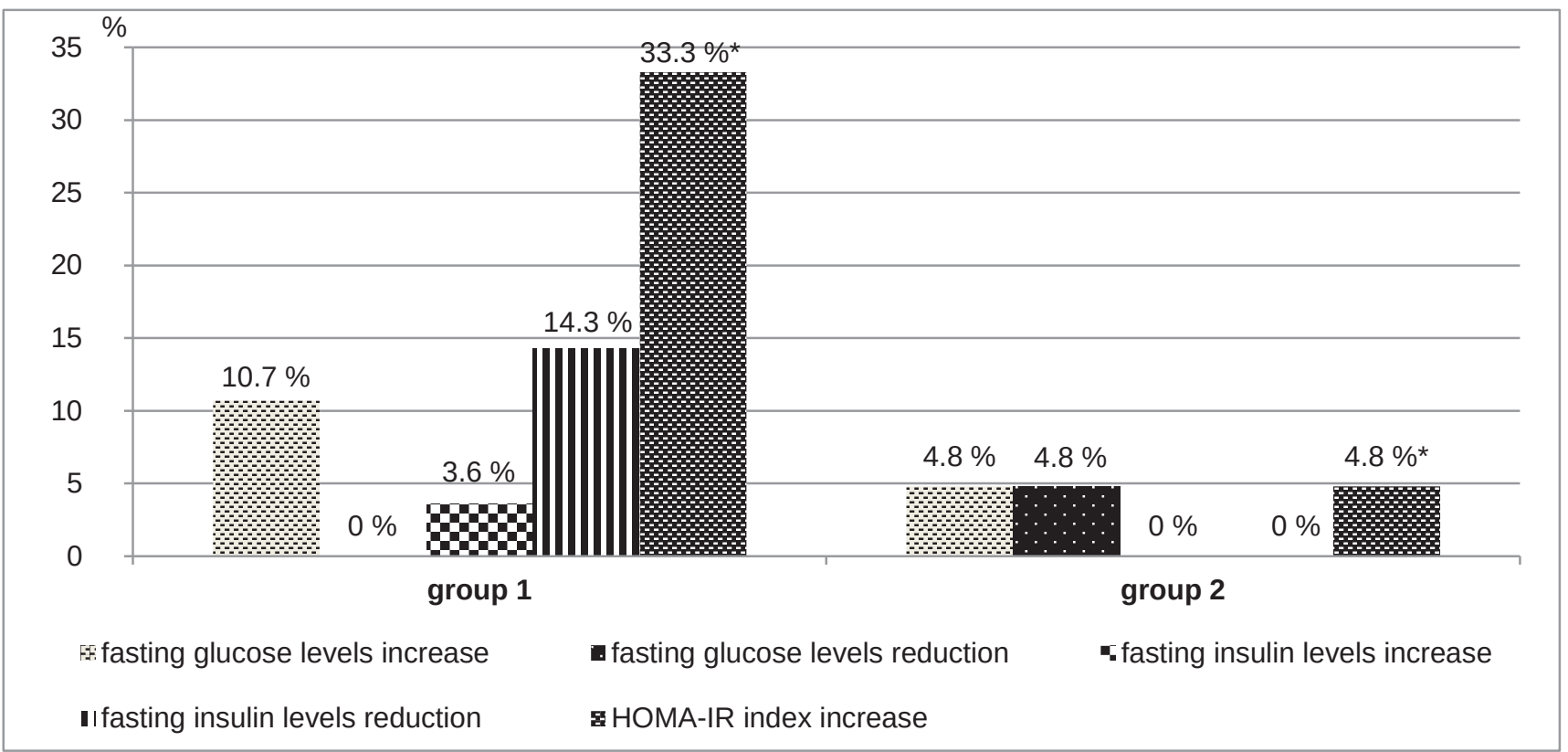

Fig. 1. The proportion of patients with different levels of fasting glucose, insulin levels, HOMA-IR index, $\%$. Note: * - significant difference between 1 and 2 groups $(p<0,05)$.

Thus, a relative slight hyperinsulinemia in normal glucose levels and HOMA-IR index increase could be a signs of preclinical disorders of carbohydrate metabolism in patients with newly diagnosed tuberculosis treatment failure. We evaluated results before and after 3 months of treatment in contradistinction to other researches. We suggested that if there is increase of HOMA-IR in the end of intensive phase of tuberculosis treatment, it would be a higher risk of TFT (differences between compared groups in HOMA-IR was $28.5 \%, \mathrm{p}<0.05)$.

It was shown, that hyperglycemia increased in MBT infected guinea pigs in 30-60 days, at the beginning of investigation glucose levels were normal [5]. We may suppose that tuberculosis infection lead to IR. But animals did 
not receive anti-tuberculosis drugs. In clinical study it was determined that there were not any changes in HOMA-IR index before and after treatment [11]. Our results coincided: there were not statistical differences in fasting glycemia, insulin and HOMA-IR before and after treatment in both groups, $p>0.05$. We may suppose, IR could be connected with tuberculosis infection.

It was established, that the appointment of anti-tuberculosis therapy did not normalize preclinical disorders of carbohydrate metabolism [1, 2]. We may support this idea: we did not receive any statistical changes in HOMA-IR after treatment. But we had not results of carbohydrate metabolism in 1 group patients before start of treatment ( 0 months), so we could estimate it when patients started treatment as TFT (3 months) and compare with results of NDT patients at the end of intensive phase (3 months).

\section{Literature}

1. Андрєєва О.Г. Гормонально-метаболічні механізми патогенезу доклінічних порушень вуглеводного обміну у хворих на туберкульоз легень / О.Г. Андрєєва // Туберкульоз, легеневі хвороби, ВІЛ-інфрекція. - 2011. - № 4(7). - С. 19-24.

2. Андрєєва О.Г. Вивчення можливостей застосування тіазолідинедіонів для корекції стану вуглеводного обміну у хворих на туберкульоз легень з доклінічними порушеннями глікемії / О.Г. Андрєєва // Український пульмонологічний журнал. - 2005. - № 3. - C. 19-22.

3. Insulin inhibits IL-10-mediated regulatory $\mathrm{T}$ cell function: implications for obesity / J.M. Han [et al.] // The journal of immunology. - 2014. - Vol. 192. - Р. 623-629.

4. Кайдашев И.П. Эволюция понятия «метаболический синдром» и его современное значение / И.П. Кайдашев // Український медичний часопис. - 2012. - № 2 (88). - С. 3-4: 157-160.

5. Non-diabetic hyperglycemia exacerbates disease severity in Mycobacterium tuberculosis infected guinea pigs / J. M. Han, S. J. Patterson, M. B. Speck [et al.] // PloS ONE. - 2012. - Vol. 7 (10). - e46824. URL: https://doi.org/10.1371/journal.pone.0046824.

6 . The role of feed regulating peptides on weight loss in patients with pulmonary tuberculosis / S. Yurt, H. Erman, G. Korkmaz [et al.] // Clinical Biochemistry. - 2013. - Vol. 46. - P. 40-44.

\section{References}

1. Andreieva, O.H. (2011). Hormonalno-metabolichni mekhanizmy patohenezu doklinichnykh porushen vuhlevodnoho obminu u khvorykh na tuberkuloz lehen [Hormonal and metabolic mechanisms of preclinical carbohydrate metabolism disturbances pathogenesis in patients with pulmonary tuberculosis]. Tuberkuloz, lehenevi khvoroby, VILinfektsiia - Tuberculosis, Lung Diseases, HIV-infection, 4 (7), 19-24 [in Ukrainian].

2. Andreieva, O.H. (2005). Vyvchennia mozhlyvostei zastosuvannia tiazolidynedioniv dlia korektsii stanu vuhlevodnoho obminu u khvorykh na tuberkuloz lehen z doklinichnymy porushenniamy hlikemii [Study of possible application of thiazolidinediones for correction of carbohydrate metabolism in pulmonary tuberculosis patients with preclinical glycae-
We can explain such differences in HOMA-IR due to impact of more virulent mycobacteria in TFT cases, more severe changes in lungs and other tissues that produce more severe oxidative stress, immunological and connected with them humoral disorders. Maybe, insulin resistance leads to worsening of tuberculosis disease prognosis due to its connection with human humoral systems.

\section{Conclusions}

We found that patients with newly diagnosed pulmonary tuberculosis treatment failure have higher fasting insulin levels and HOMA-IR index (in $33.3 \%$ more than 2.7 units, $p<0.05)$, than patients who successfully completed treatment course. It may indicate negative impact of virulent mycobacteria and more severe clinical and radiological changes on carbohydrate metabolism or/and negative impact of such disorders to prognosis of tuberculosis.

7. Берштейн Л.М. «Метаболически здоровые» лица с ожирением и метаболические признаки ожирения у лиц с нормальной массой тела: что за этим стоит? / Л.М. Берштейн, И.Г. Коваленко // Проблемы эндокринологии. - 2010. - № 3. - С. 47-51.

8. Insulin resistance: a potential marker and risk factor for active tuberculosis? / F. Mao, T. Chen, Y. Zhao [et al.] // Medical Hypotheses. - 2011. - Vol. 77. - P. 66-68.

9. Validation of HOMA-IR in a model of insulin-resistance induced by a high-fat diet in Wistar rats / L. C. Antunes, J. L. Elkfury, M. N. Jornada [et al.] // Archives of Endocrinology and Metabolism. - 2016. Vol. 60 (2). - P. 138-142.

10. Homeostasis model assessment of insulin resistance for evaluating insulin sensitivity in patients with type 2 diabetes on insulin therapy / K. Okita, H. Iwahashi, J. Kozawa [et al.] // Endocrine Journal. - 2013. - Vol. 60 (3). - P. 283-290.

11. Thanoon I. A. J. Glycemic control, serum leptin and lipid profile in patients with pulmonary tuberculosis: effect of initial two months anti-tuberculosis therapy / I. A. J. Thanoon, A. A. A. Aded-Alrahman // Al-Qadisiah Medical Journal. - 2014. - Vol. 10 (17). - P. 1-10.

12. Erol A. Visceral adipose tissue specific persistence of Mycobacterium tuberculosis may be reason for the metabolic syndrome / A. Erol // Medical Hypotheses. - 2008. - Vol. 71. - P. 222-228.

mia disturbances]. Ukrainskyi pulmonolohichnyi zhurnal - Ukrainian Pulmonology Journal, 3, 19-22 [in Ukrainian].

3. Han, J.M., Patterson, S.J., Speck, M., Ehses, J.A., \& Levings, M.K. (2014). Insulin inhibits IL-10-mediated regulatory T cell function: implications for obesity. The Journal of Immunology, 192, 623-629.

4. Kaydachev, I.P. (2012). Evolyutsiya ponyatiya «metabolicheskiy sindrom» i ego sovremennoe znachenie [The definition of metabolic syndrome: its evolution of modern meaning]. Ukrainskyi medychnyi chasopys - Ukrainian Medical Bulletin, 2 (88), 3-4, 157-160 [in Russian].

5. Podell, B.K., Ackart, D.F., Kirk, N.M., Eck, S.P., Bell, C., \& Basaraba, R.J. (2012). Non-diabetic hyperglycemia exacerbates 


\section{ОРИГІНАЛЬНІ ДОСЛІДЖЕННЯ}

disease severity in Mycobacterium tuberculosis infected guinea pigs. PloS ONE, 7(10). Retrieved from: e46824. URL: https://doi. org/10.1371/journal.pone.0046824.

6. Yurt, S., Erman, H., Korkmaz, G.G., Kozar, A.F., Uysal, P., Gelisgen, R., Simsek, G., \& Uzun, H. (2013). The role of feed regulating peptides on weight loss in patients with pulmonary tuberculosis. Clinical Bbiochemistry, 46, 40-44.

7. Bershtejn, A.M., \& Kovalenko, I.G. (2010). "Metabolicheski zdorovye" litsa s ozhireniyem i metabolicheskie priznaki ozhireniya u lits s normalnoy massoy tela: chto za etim stoit? [Metabolically healthy obese subjects and metabolic signs of obesity in subjects with normal body weight: what is behind?] Problemy endokrinologii - Problems of Endocrinology, 3, 47-51 [in Russian].

8. Mao, F., Chen, T., Zhao, Y., Zhang, C., Bai, B., Zhao, S., \& Xu, Z. (2011). Insulin resistance: a potential marker and risk factor for active tuberculosis? Medical Hypotheses, 77, 66-68.

\section{ІНСУЛІНОРЕЗИСТЕНТНІСТЬ У ХВОРИХ НА ВПЕРШЕ ДІАГНОСТОВАНИЙ ТУБЕРКУЛЬОЗ ЛЕГЕНЬ ІЗ РІЗНИМИ РЕЗУЛЬТАТАМИ ЛІКУВАННЯ}

\author{
Р.М. Ясінський
}

Запорізький державний медичний університет

Мета - оцінити рівні глюкози, інсуліну, визначених натще, та індексу homeostasis model assessment (НОМА-IP) у хворих на неефективно лікований вперше діагностований туберкульоз легень (НЛТБ), порівняно із даними пацієнтів, які успішно завершили курс лікування (ВДТБ).

матеріали і методи. Було обстежено 49 хворих на вперше діагностований туберкульоз легень. Пацієнтів розподілили на 2 групи. У 1-у групу увійшло 28 хворих на НЛТБ. У 2-у (групу порівняння) включено 11 пацієнтів із ВДТБ. Зразки крові брали перед початком лікування, через 3 міс. від початку лікування та через 2-3 міс. лікування у 1-й групі. Рівень глюкози визначали у плазмі натще гексокіназним методом із застосуванням біохімічного аналізатора Beckman Coulter AU640, Японія. Рівень інсуліну у сироватці визначали натще електрохемілюмінесцентним методом із використанням аналізатора Cobas e411, Швейцарія. НОМА-ІP вираховували за методом Matthews et al. (1985).

Результати. Рівні глюкози натще в обох групах були майже однаковими і не відрізнялися від норми ( $>>0,05)$. Рівні інсуліну натще не перевищували норму, але були вищими у хворих 1-ї групи, ніж у 2-і $(p<0,05)$. Це означало, що у них визначалася невелика відносна гіперінсулінемія. Індекс НОМА-ІР у 1-й групі також перевищував показник 2-ї групи $(p<0,05)$. Зростання рівнів глюкози натще відзначалося у
9. Antunes, L.C., Elkfury, J.L., Jornada, M.N., Foletto, K.C., \& Bertoluci, M.C. (2016). Validation of HOMA-IR in a model of insulinresistance induced by a high-fat diet in Wistar rats. Archives of endocrinology and metabolism, 60(2): 138-142.

10. Okita, K., Iwahashi, H., Kozawa, J., Okauchi, Y., Funahashi, T., Imagawa, A., Shimomura, I. (2013). Homeostasis model assessment of insulin resistance for evaluating insulin sensitivity in patients with type 2 diabetes on insulin therapy. Endocrine Journal, 60 (3), 283-290.

11. Thanoon, I.A.J., \& Aded-Alrahman, A.A.A. (2014). Glycemic control, serum leptin and lipid profile in patients with pulmonary tuberculosis: effect of initial two months anti-tuberculosis therapy. AlQadisiah Medical Journal, 10 (17), 1-10.

12. Erol, A. (2008). Visceral adipose tissue specific persistence of Mycobacterium tuberculosis may be reason for the metabolic syndrome. Medical Hypotheses, 71, 222-228.

10,7 \% пацієнтів 1-ї групи та у 4,8 \% - 2-ї групи. Зниження рівня глюкози мало місце лише у 4,8\% пацієнтів 2-ї групи. Зростання рівня інсуліну натще мало місце в 1 випадку серед хворих 1-ї групи, у 2-й групі не було жодного пацієнта із гіперінсулінемією; зниження рівнів інсуліну було зареєстровано лише у 14,3 \% хворих 1-ї групи (р>0,05). Зростання індексу НОМА-ІР відзначалося переважно серед хворих 1-ї групи: 9 випадків (33,3 \%) проти 1 (4,8 \%) у 2-й групі $(p<0,05)$. Тобто, невелика відносна гіперінсулінемія за нормальних значень глюкози та зростання індексу IP може бути ознакою доклінічних порушень вуглеводного обміну у хворих на НЛТБ.

Висновки. Це може свідчити про вплив вірулентних мікобактерій та більш тяжких рентґенологічних змін на вуглеводний обмін та/чи негативний вплив таких порушень на прогноз туберкульозу.

Ключові слова: інсулінорезистентність; туберкульоз; результати лікування.

\section{Відомості про автора:}

Ясінський Р.М. - к. мед. н., асистент кафедри фртизіатрії і пульмонології, Запорізький державний медичний університет. E-mail: phthisiologist@gmail.com

Information about author:

Yasinskyi R.M. - Candidate of Medicine, Assistant of the Department of Phthisiology and Pulmonology, Zaporizhzhia State Medical University. E-mail: phthisiologist@gmail.com

Конфрлікт інтересів: немає.

Author has no conflict of interest to declare.

Отримано 7.09.2018 р. 